\title{
前大脳動脈間吻合術の開発とその適応
}

\author{
伊藤善太郎
}

\section{A New Technique of Intracranial Interarterial Anastomosis between Distal Anterior Cerebral Arteries (ACA) for ACA Occlusion and Its Indication}

\author{
ZENTARO ITO \\ Division of Surgical Neurology, Research Institute for Brain and Blood Vessels-Akita, Akita O1O
}

\begin{abstract}
Summary
The author developed a new technique of intracranial interarterial anastomosis between distal anterior cerebral arteries (ACA).

In 1974, a case was encountered where clipping of the aneurysmal neck was difficult because the left $A_{2}$ arose from the big dome of an anterior communicating artery (Aco) aneurysm.

Before clipping of the aneurysmal neck, the left $A_{2}$ was cut off and anastomosed to the right $A_{2}$ as an end-to-side anastomosis. By this method, a new flow route to a left peripheral ACA territory was obtained via the right $A_{2}$, just as in the case of "artificial azygos anterior cerebral artery".

Thereafter, this operativc technique was modified to an easier procedure. In this report, the operative technique, its indication and its operative results are described in detail.

Bifrontal craniotomy followed by the interhemispheric approach should be performed. The anastomotic techniques were theoretically divided into four types as follows; 1) $\mathbf{A}_{2}-\mathbf{A}_{2}$ end-to-side or 2) side-to-side anastomosis at the origin of distal ACA. 3) $A_{3}-A_{3}$ end-to-side or 4) side-to-side anastomosis at the knee portion of ACA.

Among them, $A_{2}-A_{2}$ anastomosis is relatively difficult with respect to in the suturing technique because the operating field is very narrow and deep. However, $A_{3}-A_{3}$ anastomosis is easy for microsuturing because the operating field is situated superficially. By $A_{3}-A_{3}$ end-to-side anastomosis, reflow will be obtained to the proximal and to the peripheral vessels from the anastomotic part.

Inter-ACA anastomosis was applied to two cases with Aco-aneurysms and three cases with spontaneous occlusion of one sided ACA. In postoperative angiography, only 1 case with ACA occlusion, in which this technique was used 5 months after occlusion of a vessel, lacked patency. The operative indication is proposed as follows; 1) in cases with occlusion of one ACA-especially $A_{1}$ occlusion combined with hypoplasia of the $A_{c o}$ or $A_{2}-A_{3}$

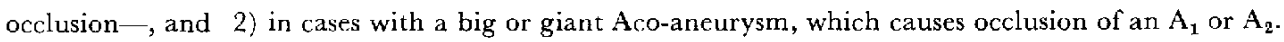

By this new technique, it becomes relatively easy to operate on cases with a big or giant Aco-aneurysm, where the direct surgical approach has, until now, been considered as difficult.
\end{abstract}

\section{Key words : cerebral arterial anastomosis, anterior cerebral artery, anterior communicating artery aneurysm, cerebral artery occlusion, giant aneurysm}

\section{Iはじめに}

1967年 Donaghy とYaşargil ${ }^{52}$ により浅側頭一中大媨
動脈吻合術（STA-MCA 吻合術）が創始されて以来，畝 血管狭窄，閉塞の部位や選択する recipient and donor vessel に応じた種々の血行再貄術が行われてきた。すな

秋田県立脳血管研究所脳神経外科

〔連絡先： $\overline{\mathbf{T}} 010$ 秋田市千秋久保田町 6-10，秋田県立䑈血管研究所脑神経外科，伊藤善太郎〕

1981 年 2 月 17 日 受稿 


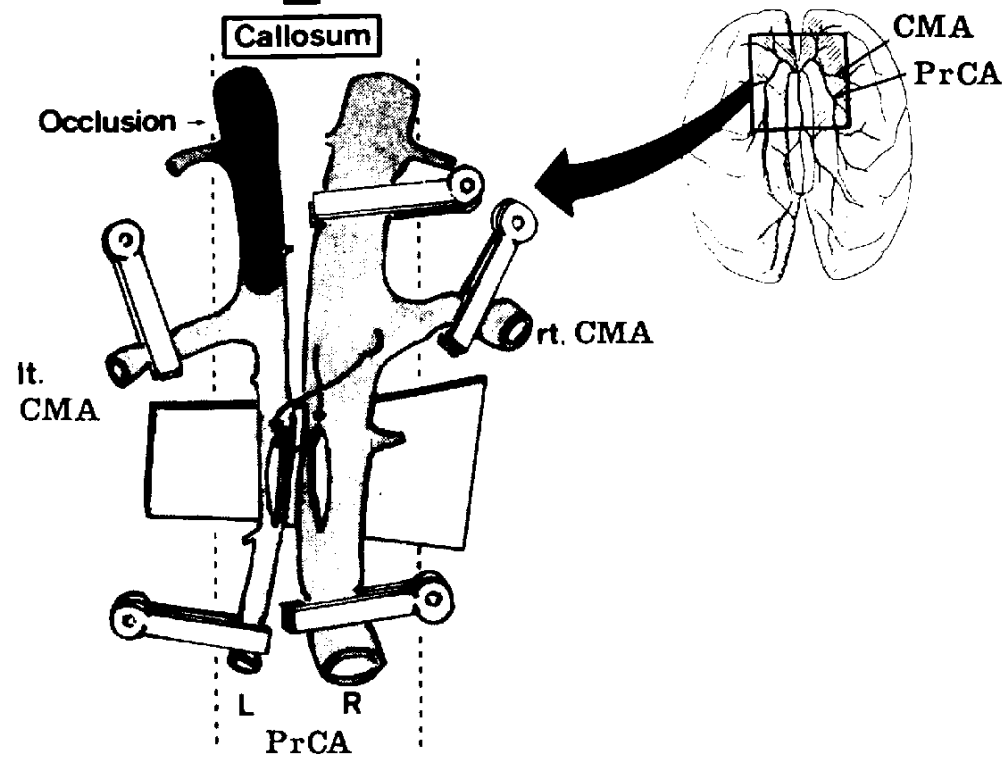

b

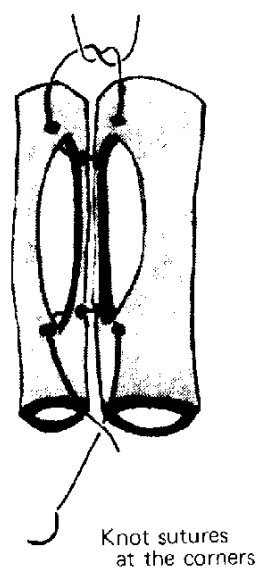

C

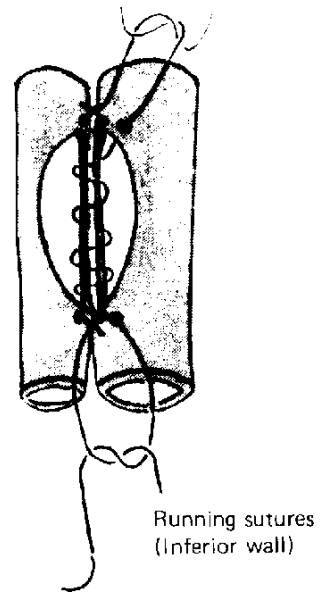

d

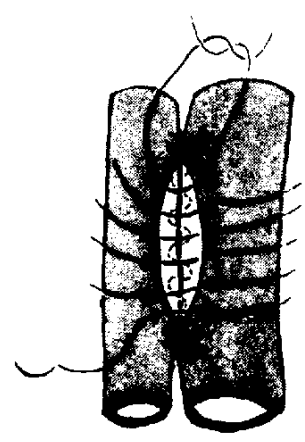

Knot sutures (Superior wall)

Fig. $1 \quad \mathrm{~A}_{3}-\mathrm{A}_{3}$ side-to-side anastomosis.

a: Selection of suitable vessels for anastomosis: Longitudinal cut should be performed more mesially on the bilateral pericallosal arteries (PrCA).

b: Knot sutures at both corners.

c: Running sutures between the inferior walls of vessels.

d: Knot sutures between the superior walls of vessels.

CMA : Callosomarginal artery, PrCA : Pericallosal artery.

The same abbreviations are used in the following figures and tables.

わち，椎骨動脈系疾患に対するもの上しては，Ausman ら ${ }^{1)}$ (1976) に上る後頭動脈一後下小脳動脈吻 合術, Corkill ら"(1977) によ万外頸動脈一椎骨動脈吻合術, radial artery graft t用いた Ausman $ら^{23}$ (1978) の椎骨
動脈一後下小脑動脈吻合街があり, 内頸動脈系に対する ものとしては STA-MCA 吻合術のほかに， saphenous vein graft 有いた Lougheed ら"2（1971）による総頸動 脈一頭蓋内内钼動脈吻合術, Story $b^{\text {13) }}$ (1978) kよる 


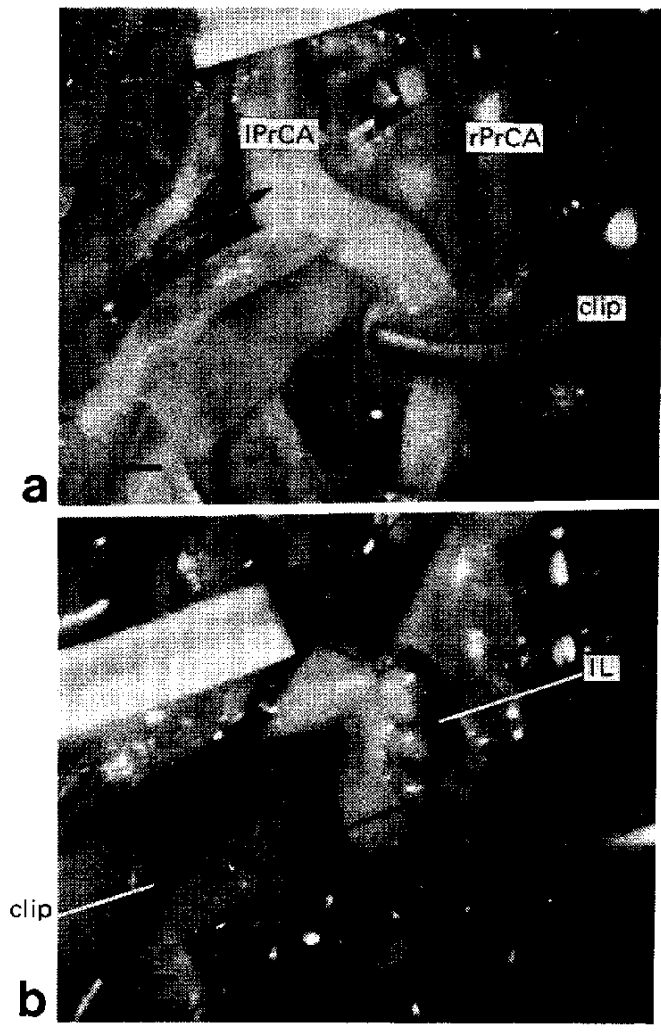

同 graft による頚動脈一中大䋃動脈吻合術, radial artery graft 学用いた Chater ${ }^{32}$ による外頸動脈一中大脳動脈皮 質枝吻合術，私の同 graft 学用いた外（または内，むた は総）頸動脈一中大脳動脈鳥回枝哆合術 ${ }^{83}$ ，後頭動脈一 中大腷動脈皮質枝吻合術"1なよ゙である。しがながら， 頭葐内血管閒の吻合術，特に前大脳動脈 (ACA) 系閉塞 狭窄に対しての血行再建術の報告はない，私は1974年， 左前大脬動脈 $A_{2}$ 部が動脈瘤より起始している大きな前 交通動脈動脈瘤手術に際し，左 $A_{2}$ を切断せざるをえな い症例に遭遇し，切断した左 $\mathrm{A}_{2}$ を右 $\mathrm{A}_{2}$ に端側吻合を 行い, 人為的 azygos anterior ccrebral artery L \&い5 き新経路を作成する機会を得た”。 その後，本法を漸次 改良 L，種々 0 原因による前大脳動脈（ACA）閉塞に対 ᄂ , Inter-ACA 吻合術 (Intracranial interarterial anastomosis between distal $\Lambda \mathrm{CAs})$ t行ってきた。本論文 では本手術法の手技执よびその間題点とその適応につい て報告与る。

\section{II 手術手技： $\mathbf{A}_{3}-\mathbf{A}_{3}$ 側側吻合術}

種々の原因によるACA 起始部閉塞に対する同名動脈

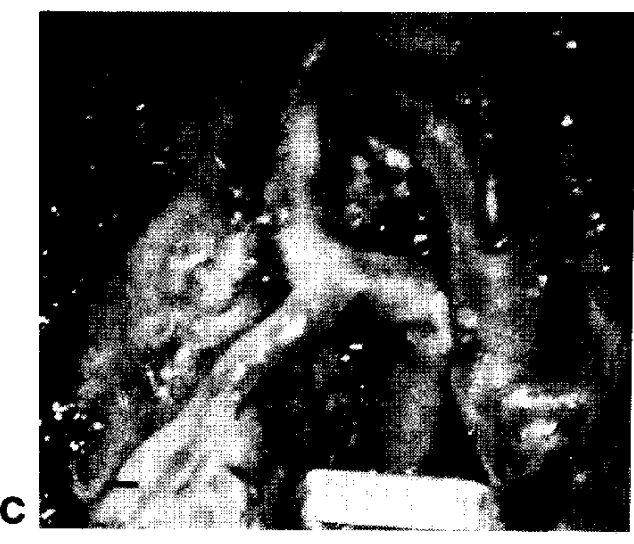

Fig. 2 Intra-operative photographs of $A_{3}-A_{3}$ sideto-side anastomosis (Case 4 ).

a: Temporary clipping at the peripheral parts of bilateral PrCAs. Note the narrow caliber of a left PrCA with an occlusion on its proximal part $(\rightarrow)$.

$\mathrm{b}$ : Running sutures between the inferior walls of bilateral PrCAs.

c: $\mathrm{An}_{\mathbf{3}}-\mathrm{A}_{3}$ side-to-side anastomosis is completed.

The caliber of the left pericallosal artery was enlarged at its peripheral part by reflow after release of temporary clips, but the followup angiography demonstrated occlusion of the anastomotic site of the left PrCA.

間吻合術としては，理論的には4つの方法が考元られ

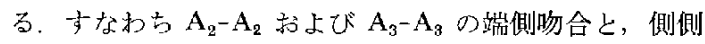
吻合の各組及合わせである，しかし奏際には，深部での 狭い間隔に括订る微小縫合には高度に熟練したテクニッ クが必要になる。もっとも容易な吻合法は ACA 膝部に 怙ける端側生たは側側吻合であるう。本項では，現在行

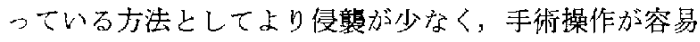
で, 中枢和よび末梢側いの血行が得られる $A_{3}-A_{3}$ 側側吻 合術の手技についての灭詳述する。

\section{1. 皮切, 開頭およひ接近法}

患者江仰卧位で頭位は上向き水平とする。皮切湔頍

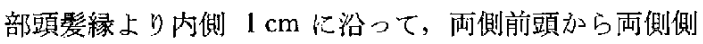
頭筋上䋑までのばす，開頙恃岀側前頭開頭で，前頭洞を 開放しないようにする，頭蓋内手術操作を行いゃすく寸 るために，開頭前にマニットール点滴静注により脳窝積 減少せしめて招くが，これが不十分な場合は開頭後に 右側脳室前角を穿刺し，髄液孝適当量排除しておく。硬 膜は後方凸の弓状に両側になたがるよらに切開し, 最前 端で大脳鎌を結梦切断する，ついで大媨裂間剥離を行 い，䅨梁膝部の ACA に達する。 ついで, callosomargi- 
nal artery (CMA) 分岐直後で, 両側 pericallosal artery (PrCA) 加两側前顽葉の半球裂面に向加5微小枝を $1 \sim 3$ 本焼却切断する. $1.5 \sim 2.0 \mathrm{~cm}$ 遊離された両側 pericallosal artery 下に脑被護烐のゴム小片を引く(Fig. 1，2a)。この際両侧 PrCA をたがいに引き寄せるよらに 寸る. 通常 $\operatorname{PrCA}$ 外径は約 $2 \sim 3 \mathrm{~mm}$ であるが, 閉塞例 $\operatorname{PrCA}$ 法上り細い，脳表から PrCA までの距離注平均 3 〜 $5 \mathrm{~cm}$ である.

\section{2. 両側 pericallosal artery (PrCA) の一時遮断}

(Fig. 2a)

比較的深部での側側吻合のために，遮断用クリップの 選択上一時遮断部位に留意才る必要がある。タリップは Yaşargil の弯曲型微小血管用タリップが適当と思われ る。原則として両側 PrCA の心臟側上末梢側を両側加ら 寄せるよらにしてクリップ1本で遮断する.このように す当と術野が見や寸くなり，以下の手術操作が行いやす くなる。

\section{3. 血管壁の切載}

両側 $\mathrm{PrCA}$ に各々約 $2 \mathrm{~mm}$ の縱切開充加える.この 際，術者より見て，血管の中央部を切載するのではな く，両側とも $\mathrm{PrCA}$ のや内側笴りに切開孛加えるのが 上い，血管内血塊をへパリン扣生塩水で洗い流す。

\section{4. 吻合手順}

1) Cornering suture：まず，血管の縦切開両端に 10-0または11-0ナイロンモノフィラメント采で結節

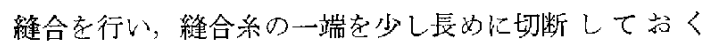
(Fig. 1b).

2）下壁の running suture (Fig. 1c，2b)：心葴側切 開端外壁上り釙采を通し，その系端は先に長为比切断し て捛いた cornering suture の糸と絬紫する.ついで下壁 の連続縫合行 万。最終的には来梢側切開端外壁に出し た糸上，すでにその部位に行ってある corncring suture の縫合采上結紫する (Fig. 1c).それに先だち，血管内膜

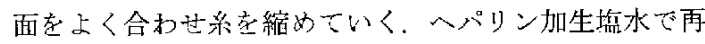
度血管腔内在洗浄寸る。

3）表壁の結節縫合 (Fig. 1d，2c）：血管の切開部表 壁活結節縫合する. まず左右 $\mathrm{PrCA}$ の表壁交約 $0.2 \mathrm{~mm}$ 閒隔て縫合系を通し，その采は適当な長さに切断して揖 き，のちに一括して結紮する，最後の1２糸絬禁主 る前にへパリン加生塩水で血管腔内在洗浄し，これ渵 たして㧍く，通常，10数針が必要である。タリップは末 梢端よりはずす，吻合部からの小出血があった場合は， 綿片による圧迫で容易に止血しらる。吻合所用時間は15 〜25分ほどであり，微小剪錟，持針器，ピンセットなど はSTA-MCA 吻合術用のもの上り長妙のものが有利で
岕る、術中心はへパリンの全身投与法行わない，

4）吻合後処㯰：吻合完成後，吻合部血管を湓酸パパ ベリン綿で覆っておく、吻合部開通が得られた場合，閉 塞 ACA は緊満し，征怔搪大する，止血確認後，一次的 飞開頭する。術後江低分子デキストラン $500 \mathrm{ml} / \mathrm{H}$ 日点滴 静注を約 1 週間行う。術後 $\mathrm{C} T$ スキャンまたは脳血管撮 影は早めに行い，吻合後の脑の状態または吻合部開存の 有無老確かめて打く。

\section{II 症例}

前交通動脈動脈瘤手術による $\mathrm{A}_{2}$ 切断または閉塞各 1 例, $\mathrm{A}_{1}, \mathrm{~A}_{2}-\mathrm{A}_{3}, \mathrm{~A}_{3}$ の自然閉塞各 1 例計 5 例k Inter $\mathrm{ACA}$ 吻合術を行っている. $A_{2}-A_{2}$ 端側吻合 1 例, $A_{3}-A_{3}$ 側側吻合の夕 3 例, $\mathrm{A}_{3}-\mathrm{A}_{3}$ 側側吻合と STA-MCA 吻合 の合併手術 1 例であり, Table 1 示寸ように，閉塞か ら吻合手術までの期間が 4 力月までのもの注開通してい る，以下に端側挹上び侧侧吻合術を行った代表例孝提示 する。

\section{1. $\mathbf{A}_{\mathbf{2}}-\mathbf{A}_{2}$ 端側吻合術例}

<39才, 男性, 右利き, 農業, 前交通動脈動脈瘤〉

入院 2 力月前, 頭痛扔よび腿前暗転発作で発症した。 術前脳血管撮影で前交通動脈に大きな動㟲虚を発見 乙 た，動脈瘤の径は11 mmであり，動脈溜瑻恃分離しえ ず，左 $A_{2}$ 注瘤より起始しているようにみえた(Fig.

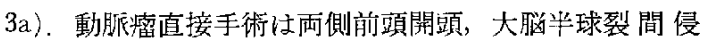

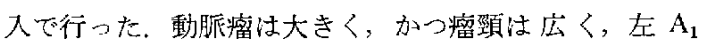
法動脈溜中央部より起始していた。このままで注瘤頸ク リッピングは不可能と考えられた. 左 $\mathrm{A}_{2}$ 切断し右 $\mathrm{A}_{2}$ 起始部江端側吻合して, 人為的 azygos anterior cerebral artery ともいうべき新経路を作製し，同時に動㟲瘤 頸クリッピングを行った (Fig. 4)。ACA 遮断時間は40 分であった。両側 $\mathrm{A}_{1}$ 外径はほぼ同大であり，非破裂動 眽㾴であった。

術後脳血管撮影（術後７日目）では，動脈癐は完全に 消失し, 左 $A_{2}$ 以下江右 $A_{2}$ 加右一左 $A_{2}$ 吻合部を介 して順行性に造影されている (Fig. 3b).

術後はごく一過性に軽度意識障害扔よび右下肢脱力が 出現したが, 術後11日目に神経学的脱落症状もなく退院 した。この手術は distal ACA 間吻合術の第 1 例であっ たが，術野が深部で狭いらえに左側の切断 $\mathrm{A}_{2}$ の長さに 余裕がなく，吻合操作はきわかて困難であった．

\section{2. $\mathbf{A}_{3}-\mathbf{A}_{3}$ 側側吻合術例}

$<47$ 才, 男性, 右利き, 団体識員, 右 $\mathrm{A}_{2}-\mathrm{A}_{3}$ 部閉塞+左 頸部内頸動脈閉塞>

昭和 53 年 8 月末より頭痛，左上肢シビレ感があり， 9 

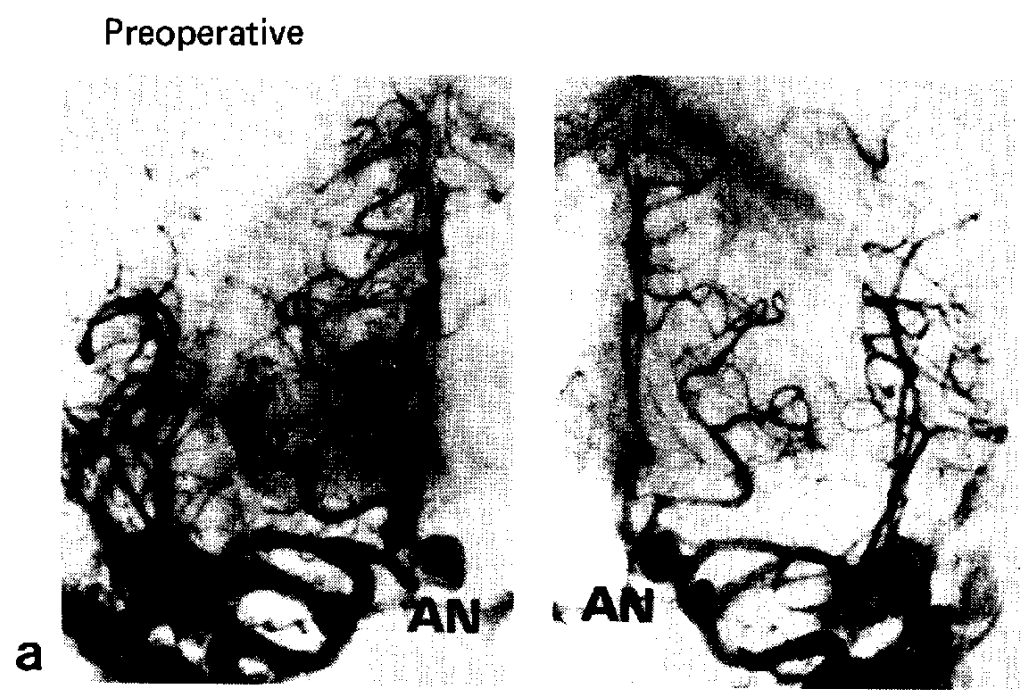

\section{Postoperative}
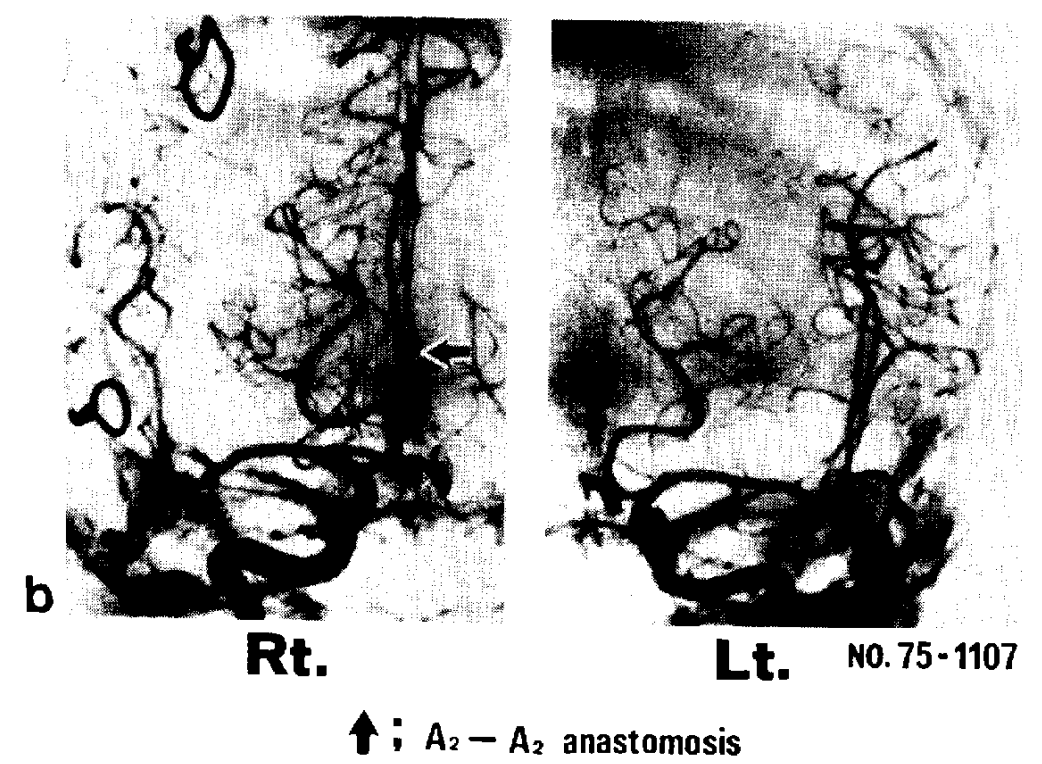

Fig. 3 Bilateral carotid angiograms before and after the $A_{2}-A_{2}$ end-to-side anastomosis in Case 1 .

a: Preoperative angiograms: A big aneurysm (AN) of the anterior communicating artery (Aco) is observed. The origin of the left $A_{2}$ cannot be clarified in this film.

b: Postoperative angiograms. A left distal ACA is demonstrated via a new anastomotic channel from a right $\mathrm{A}_{2}$. The aneurysm of the Aco disappearcd.

月中旬上り発語障青，失神発作が $4 \sim 5$ 回出現し， 9 月 29 日釧路労災病院脳神経外科女受診した。この屓上り軽 度の右上下肢脱ナがあった。 10月11日の 4-vessel angiographyにて，上記診断がなされた (Fig. 5a)，侧副路は

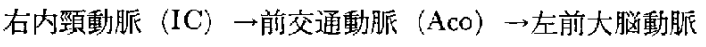

( $\mathrm{ACA}$ ) と中大媨動脈 (MCA) 抒よび椎骨動脈一左後 大脑動脈 $\rightarrow$ 左 $\mathrm{ACA}, \mathrm{MCA} の 2$ 経路であり, CTで法軽 度の全般的脳䔔縮がみられた。去の後アスピリン 0.6 $\mathrm{g} /$ 日投与老行ったが，右上下肢脱力の増悪発作が連日 繰り返し出現している。 
12月 5 日, 左 STA-MCA double anastomoses と同時 に $\mathrm{A}_{3}-\mathrm{A}_{3}$ 側側吻合術学行った。 右 ACA は有 callosomarginal artery 含め，膝部より中枢側で完全開塞が京 り，それ以降の pericallosal artery 血管壁肥厚や狭少 化がみられた，術後一過性の失見当識，右下肢脱力増要 が办ら机たが，術前みられた神経症状の増悪発作岋な く，昭和54年 1 月 8 日，ほほ術前の状態で退院した。術 後、アスピリン投与恃釈続している。它の後も脱力発作 はみら机ず，しかも，術後約 2 力月に法街みられた右
上下肢脱力もほぼ完全に消失し，原職復㷌後 2 年余を経 過している。

術後の左頸動脈摄影では，左 STA なんて左 MCA 領城のほぼ全城が造影され，右頸動脈撮影では， $A_{2}-A_{2}$ 吻合部を介し，左 ACA から右 $\Lambda \mathrm{CA}$ 末梢部が造影され ている (Fig. 5b, c).

(本症例性制路学多病院脳神経外科上て私が手術を行 ったものであり，同科部長小岩光行氏の御好意により 提示した.)

$$
\mathrm{V} \text { 考 察 }
$$

現在，脳血管閉塞・狭窄に上る脸虚血に対して，または ある種の腫瘍や脳動脈瘤に抢ける補助手街手段326)1012 として，種々の頭蓋内外血管吻合術が行われている，す なわち，浅側頭動脈一中大脳動脈皮質枝吻合術，後頭動 脈一後下小腷動脈吻合術および動また注静脈遊離 $\mathrm{graft}$ を用いた種々の吻合術などである。しかしながら頭蓋内 血管間吻合術の報告注，Ausman らの遊離 graft t用い た椎骨動脈一後下小媨動脈吻合街”除いてはみられな い. 私はこれまで，頭蓋内血管閒吻合術として，中大脳

Fig. 4 Schematic diagram of $\mathbf{A}_{\mathbf{2}}-\mathbf{A}_{2}$ end-to-side anastomosis and clipping of Aco aneurysm in Case 1.

\section{postoperative CAG}

\section{Preaperative CAC}

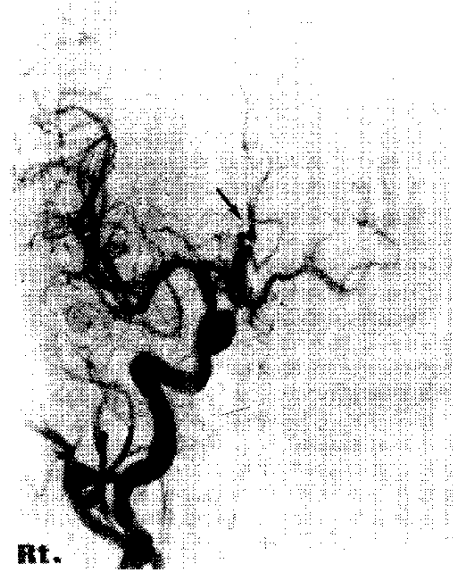

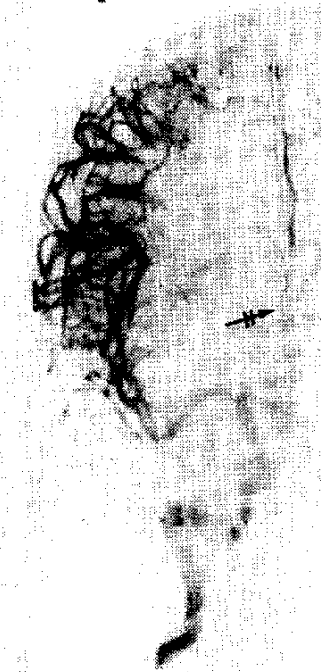

nt.

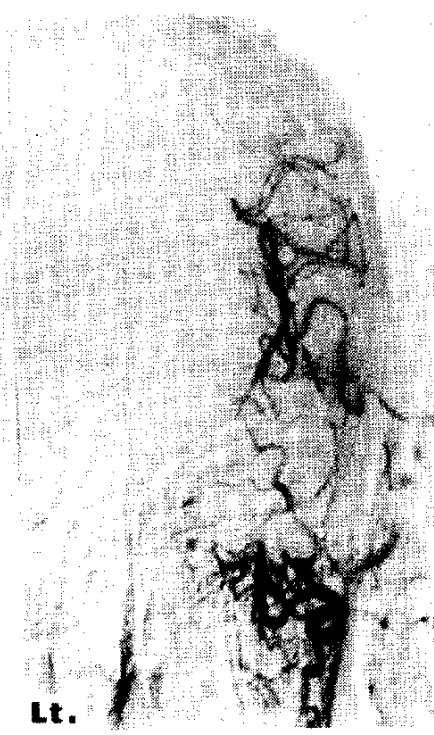

b

Fig. 5 Carotid angiograms before and after $\mathrm{A}_{3}-\mathrm{A}_{3}$ side-to-side anastomosis and STA-MCA anastomosis in Case 5 , which had a left cervical intcrnal carotid occlusion and a right $\mathrm{A}_{2}-\mathrm{A}_{3}$ occlusion.

a: Preoperative study (right carotid angiogram). Note a right $A_{2}-A_{3}$ occlusion $(\rightarrow)$ and a left distal $A C A$ filled via the Aco from the right $\mathrm{A}_{1}$.

b: Postoperative study (bilateral carotid angiograms). The right $A_{3}$ is filled via a $A_{3}-A_{3}$ anastomotic channel $(+)$ from the left ACA and the left MCA territory is also filled via a left STA-MCA bypass graft $(\rightarrow)$ 
動脈島回枝間吻合術および前大脑動脈 間昒 合術 InterACA 吻合術を行ってきだ、. 本論文では Inter-ACA 吻 合術の手術手技，適応等について述べ，本法の問題点を
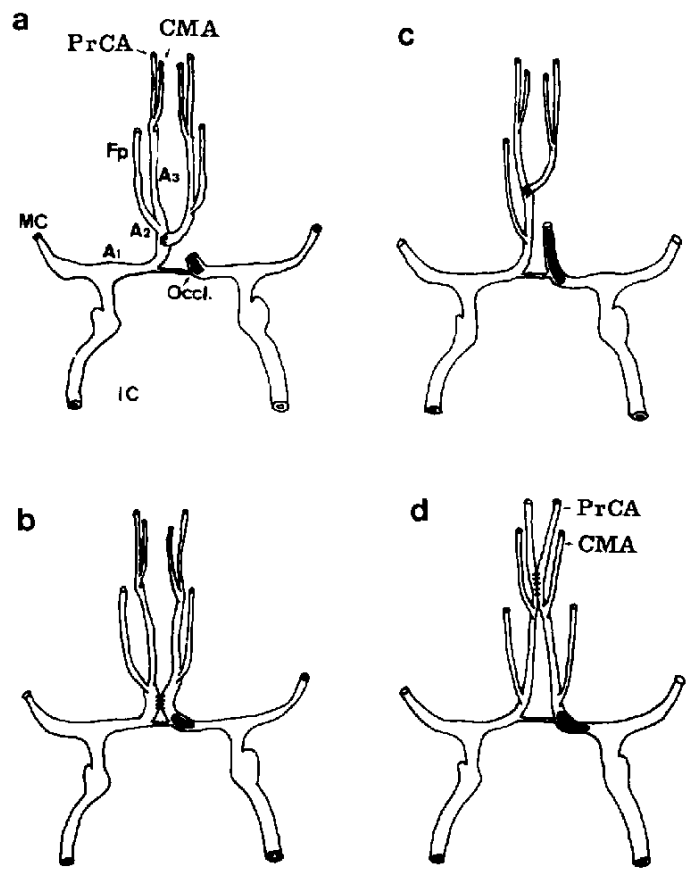

Fig. 6 Various types of inter-ACA anastomosis theoretically considered.

a: $\mathrm{A}_{2}-\mathrm{A}_{2}$ end-to-side anastomosis.

b: $\mathrm{A}_{2}-\mathrm{A}_{2}$ side-to-side anastomosis.

c: $\mathbf{A}_{3}-\mathbf{A}_{3}$ end-to-side anastomosis.

d: $A_{3}-A_{3}$ side-to-side anastomosis-this procedure is superior to others.
考察した

\section{1. 手術方法}

Distal ACA 間で吻合を行い，い加ば人為的 azygos anterior cerebral artery とむいうべき新経路を作製する 場合, 理論的には 4 つの方法が考えられる。すなわち， (1) $\mathrm{A}_{2}-\mathrm{A}_{2}$ 端側，末たは(2)側側吻 合, (3) $\mathrm{A}_{3}-\mathrm{A}_{3}$ 端側吻 合, (4) $A_{3}-A_{3}$ 側側吻合である (Fig，6).

(1)の吻合術は Case 1 において央際に行ったものである が，大腷裂間侵入に招ける吻合手技は術野が深部で（脳 表より約 $8 \sim 9 \mathrm{~cm}$ ), 狭い間隙のためきわめて困難であ った．切断した $\mathrm{A}_{2}$ の長さに余裕がないため，吻合血管 の内側面は連続縫合を行っているが，この操作は深部で 狭险な術野では難しく，汃内膜の適合に難があると考 えられた．(2)は行っていないが同様の困難性をより多く もつものと考㝋られる。し加し $\mathrm{A}_{2}-\mathbf{A}_{2}$ 吻合術忙，手術手 技が困難といら点除外すれば，閉塞側 ACA の血流が 上り中枢側より順行性に得られるといら点て優れている と考えられ，今後手技拉よび器具の改良があ玌ぜ行って 上い方法加もしれない（31施行していない，しかし， frontoporal artery 分岐後まで閉塞が及んでいる場合は， 同側の pericallosal artery (PrCA) を切断して脳梁膝部 での端側吻合を行ってもよいと思われる。(4注現在通常 行っている方法である。 その手技の実際については本文 中に記述してある. (3)，(4)の方法は比較的浅く広い術野 で手術を行うことが可能で，特に(4)の場合は frontoporal artery 一の逆行性血流得ることにもなる．以上のこと をを上めると，(1)，(3)，(4)が行いらると考えられるが， (4)が実用的であると考えている.

\section{2. 手術結果}

現在まで 5 例に手術を行っている（Table 1 )，前交通

Table 1 Case summary

\begin{tabular}{|c|c|c|c|c|c|c|}
\hline Case & Age & Sex & Diagnosis & $\begin{array}{l}\text { Operative } \\
\text { procedure }\end{array}$ & $\begin{array}{l}\text { Occlusion } \\
\text { anastomosis }\end{array}$ & Patency \\
\hline 1. & 39 & $\mathbf{M}$ & $\begin{array}{l}\text { Cut off } 1 \mathrm{t} . \mathrm{A}_{2} \\
\text { (Big anterior communicating aneurysm) }\end{array}$ & $A_{2}-A_{2} E \cdot S$ & immediately & + \\
\hline 2 . & 54 & $\mathrm{M}$ & $\begin{array}{l}\text { 1t. Af occlusion } \\
\text { (After surgery on anterior communicating aneurysm) }\end{array}$ & $A_{3}-A_{3} S \cdot S$ & $4 \mathrm{~m} \mathrm{13d}$ & + \\
\hline 3. & 54 & $\mathrm{M}$ & lt. A, occlusion + lt. IC stenosis & $A_{3}-A_{3} S \cdot S$ & $38 d$ & + \\
\hline 4. & 50 & $\mathbf{M}$ & lt. $A_{2}-A_{3}$ occlusion & $A_{3}-A_{3} S \cdot S$ & $5 \mathrm{~m} 21 \mathrm{~d}$ & - \\
\hline 5. & 47 & $\mathbf{M}$ & rt. $A_{3}$ occlusion + lt. IC occlusion & $\begin{array}{c}\mathrm{A}_{3}-\mathrm{A}_{3} \mathrm{~S} \cdot \mathrm{S} \\
+ \\
\text { 1t. } \mathrm{ST}-\mathrm{MC}\end{array}$ & $4 \mathrm{~m}$ & + \\
\hline
\end{tabular}

IC : Internal carotid artery, MC : Middle cerebral artery, ST : Superficial temporal artery, ST-MC : ST-MC bypass, S S : Side-to-side anastomosis, E $\cdot \mathrm{S}:$ End-to-side anas tomosis 
動脈瘤に関与する症例としては，大きな前交通動脈瘤で 左 $\mathrm{A}_{2}$ が瘤より起始している症例の動脈瘤直接手術に際 しそその $\mathrm{A}_{2}$ 切断し，ただちに $\mathrm{A}_{\mathbf{2}}-\mathrm{A}_{2}$ 端側吻合を行い， 動脈瘤頸部クリッピングを行ったもの 1 例 (Case 1), 前 交通動脈瘤頸部クリッピング後左 $\mathrm{A}_{2}$ 閉塞をきたし，4 力月 13 日後に $A_{3}-\Lambda_{3}$ 側側吻合去行った 1 例 (Case 2) で ある。 $\mathrm{A}_{1}, \mathrm{~A}_{2}$ また住 $\mathrm{A}_{3}$ の血栓閉塞例は 3 例 (Case 3 ， 4,5) で，いずれも $A_{3}-A_{3}$ 側側吻合を行っているが，一 側内頸動脈閉塞合併の minor stroke 1 例 (Case 5) では, STA-MCA double anastomoses \&同時に行っている.

左、 $\mathrm{A}_{2-3}$ 部閉塞で発症後 5 力月 21 日目に手術を行った 1 例（Case 4)を除き，術後脳血管撮影で吻合部開存が 証明されている。吻合部閉塞例は術前脑血管撮影で distal ACA 一の逆行造影度が不良で，手術時红左 ACA の 著明な塽少化や血管壁肥厚が認められたものであり，閉 塞側 $\mathrm{ACA}$ 末梢部自体に問題があったものと考えられ た.

\section{3. 手術適応亡手術時期}

本法の手術適応例としては Aco 形成不全を伴 う一側 $\mathrm{A}_{1}$ 閉塞，または一側 $\mathrm{A}_{2}-\mathrm{A}_{3}$ 㧍よび膝部 $\mathrm{A}_{3}$ 閉塞などの $\mathrm{ACA}$ 一側血栓, 塞栓閉塞例, あるい忙 Aco-complex 動 脈瘤手術に際し，主に大また法巨大動脈瘤で，一側 $A_{1}$ または $\mathrm{A}_{2}$ 老切断または閉塞せざるをえないるの，trapping などで一側 $A_{2}$ 以下の血行不全が推測されるもの, troubled operationにより一側 $\mathrm{A}_{1}$ または $\mathrm{A}_{2}$ を開塞せし めたものなどが考えられよら。本手術の時期としては Aco-complex 動脈溜手術に招いては同時に行らことが望 \&し、, 一方 $\mathrm{A}_{2}-\mathrm{A}_{3}$ 血栓閉塞例で江，発症後連続腷血管 撮影を経時的に行って $\mathrm{ACA} の$ 逆行造影度を検討してみ ると, 後大腷また法中大腷動脈加ら leptomeningeal anastomosis を介しての逆行造影開が時間上ともに減少して いく傾向がみられる。このことは中大脑動脈と比較する と，長い経路をもち，側枝加比較的少ない $\mathrm{ACA}$ におい ては，いったん起始部閉塞が起こると $\mathrm{ACA}$ 主幹部内で は血流減少が著しく，血管壁の二次的変化抒よび血流停 滞による血管腔内の血栓形成などが起こりやすいためで 注ないかと考えられる。そ結果, 発症後長期経過後の 吻合例で法，その開存率吕低下寸るのではないかと考え られる。

今回のシリーズでは, 発症約 4 力月半後の手術例では 吻合部開存が得られていたが，5力月21日目に手術を行 ったものは吻合血管の二次的病変が高度で開存が得られ なかった，手術手技や吻合血管の状態が吻合開存に大き な影響を及ぼすの注当然であるが，吻合時期もできるだ け早期, 少なくとも ACA 閉塞後 $3 \sim 4$ 力月以内に手術
を行らことが開存率を高めることになるものと思われ る.

現在なお症例も少なく，その結果を明確に論ずるに至 っていないが，この新しい手術法により，特にこれまで 困難とされた Aco-complex の大また注巨大動脈瘤, ま た法 troubled operation 後 ACA 閉塞例に対しても対処 可能となり，従来まったく治療不能であった $\mathrm{ACA}$ 自然 閉塞例に対しても何らかの治療の可能性をもたらしたも のといえよう。

\section{V 結 語}

1. 頭蓋内動脈間吻合術一Inter-ACA 吻合術一を 創 案した。

2. 脳梁滕部 ACA 間儧側吻合術が手術操作の難易 度, 招上び新血行路形成のパターンなどからみて妥当な 手術法であった。

3. 手術適応は Aco-complex の大・巨大動脈瘤で,一 側 $A_{1}$ また注 $A_{2}$ 老特牲にする場合，お上び troubled operation で一側 $A_{2}$ 䘮閉塞したもの trapping 適応例で, 一側 $\mathrm{A}_{2}$ 以下の血行不全が予測されるもの，拉よび Aco 形成不全伴 5 一側 $\mathrm{A}_{2}$ 自然閉塞例, 一側 $\mathrm{A}_{2}-\mathrm{A}_{3}$ 自然 閉塞例である.

本論艾の要旨は, 第38回日本媨神経外科学会粉会 （1979，真京）に招いて報告した。

\section{文献}

1) Ausman, J. I., Lee, M. C., Klassen, A. C., Seljeskog, E. L. \& Crou, S. N.: What's new? Cerebral revascularization. Minn Med 58: 223227, 1976

2) Ausman, J. I., Nicoloff, D. M. \& Chou, S. N.: Posterior fossa revascularization: anastomosis of vertebral artery to PICA with interposed radial artery graft. Surg Neurol 9: 281-286, 1978

3) Chater, N.: Microsurgical vascular bypass for occlusive cerebrovascular disease. pp 363378, In Rand, R. W. (ed): Microneurosurgery, 2nd Ed., C. V. Mosby, St. Louis, 1978

4) Corkill, G., French, B. N., Michas, C., CABB, C. A., III. \& Mims, T. J.: External carotid-vertebral artery anastomosis for vertebrovasilar insufficiency. Surg Neurol 7: 109115,1977

5) Dovaghy, P. \& Yaß̧argil, G.: Extra-intracranial blood flow diversion. American Association of Neurological Surgcons. April 11, Chicago, Illinois, 1968 
6) Hopkins, L. N. \& GRANd, W.: Extracranialintracranial arterial bypass in the treatment of aneurysms of the carotid and middle cerebral arteries. Neurosurgery 5:21-31, 1979

7) 伊藤善太郎：Distal ACA 吻合術の創案とその 適応，第38回 日本脑神経外科学会総会, 東京, 1979

8) ITo, Z. : Extra-intracranial arterial bypass with long radial artery graft. 5th International Symposium on Microvascular Anastomoses for Cerebral Ischemia, Sep., Vienna, Austria, 1980

9) Lougheed, W. M., Marshall, B. M., Hunter, M., Michei., E. R. \& SandwithSMYTH, H.: Common carotid to intracranial internal carotid bypass venous graft. Technical note. J Neurosurg 34: 114-1 18, 1971

10）柇 表右, 菊池晴彦, 古瀬清次, 唐澤 淳, 吉田泰二, 大西英之, 湧田幸雄, 滝 和郎 : 譄 血管異常に対し，trapping 必要とする䟢の STA-MCA anastomosis $の$ 有用性(The usefulness of STA-MCA anastomosis in trapping vascular disorder). 媨外 $5: 253-259,1977$

11) Spetzler, R. \& Chater, N.: Occipital artery-middle cerebral anastomosis for cerebral artery occlusive disease. Surg Neurol 2: 235-238, 1974

12) Spetzler, R. F., Schuster, H. \& Roski, R. A. : Elective extracranial-intracranial arterial bypass in the treatment of inoperable giant aneurysms of the internal carotid artery. $J$ Neurosurg 53: 22-27, 1980

13) Story, G. L., Brown, W. E., Emelberg, E., Alom, K. V. \& Stewart, J. R.: Cerebral revascularization: common carotid to distal middle cerebral artery bypass. Neurosurgery 2: 131-134, 1978 